\title{
Developing Entrepreneurial Skills. An Educational and Intercultural Perspective
}

\section{Ramona - Diana Leon ${ }^{1}$}

\begin{abstract}
The research aims to determine how the economic and business administration faculties within the European Union member states are contributing to the development of students' entrepreneurial skills. Therefore, a case study strategy is employed which concentrates on the most important business schools from the European Union member states; thus, 267 syllabuses from 21 higher education institutions are identified and analyzed. The results prove that European business schools manage to develop most of the required entrepreneurial skills among their students. Their graduates are both task and people oriented. On the one hand, they value performance, are capable of solving problems and taking calculated risks. On the other hand, they know how to communicate and collaborate within a team. Besides, it may be stated that the analyzed educational programs are combining the "about entrepreneurship" approach with "for entrepreneurship" perspective; they focus on developing cognitive, functional, and behavioral competences by combining lectures with active learning techniques. These actions are influenced by cultural specificity and have an impact on a country's capacity to be a top performer, in terms of entrepreneurship development. These findings have both theoretical and practical implications. On a theoretical level, they extend the literature regarding the development of entrepreneurial skills by providing concrete information about the skills on which the academic curricula focus. On a practical level, they provide valuable insights regarding the skills that the future entrepreneurs will have; these will influence their behavior in a business environment no matter whether they will choose to be the owner of a business or an enterprising employee.
\end{abstract}

Keywords: entrepreneurship, risk-taking, communication, university, European Union.

1 Ramona - Diana Leon, Senior Lecturer, National University of Political Studies and Administration, 30A Expozitiei Blvd., Sector 1, 012104, Bucharest, Romania, e-mail: ramona.leon@facultateademanagement.ro. 


\section{INTRODUCTION}

Within the framework of a dynamic and unpredictable environment, entrepreneurship appears as a possible incentive for sustainable development. According to GEM (2014), this is a complex activity that fosters economic growth through innovation, job creation and wealth. Entrepreneurs are those responsible for challenging the status-quo, discovering new profitable opportunities, and exploiting new ways of doing things. But what skills do they have and where did they acquire them?

\section{LITERATURE REVIEW}

The European Council (2006) labelled entrepreneurship as one of the eight key competences that all individuals should have in order to facilitate business creation and innovation (Landström, Harirchi \& Åström, 2012) and to have a successful professional life (Daniel, Costa, Pita \& Costa, 2017); the entrepreneur is seen not only as a person who is capable of taking risks and starting a business but also as an individual who uses his/her skills and characteristics in order to create value in a company (Gundry, Ofstein \& Kickul, 2014). Thus, the programs developed in higher education institutions start to focus on teaching and improving individual's entrepreneurial skills (Daniel et al., 2017; Hannon, 2006; Katz, 2008; Schelfhout, Bruggeman \& de Maeyer, 2016), and take into account the fact that their graduates may become either self-employed or innovative employees.

However, their task gets harder when it comes to defining which skills they should develop. As can be noticed from Table 1, plenty of research has been made regarding entrepreneurial skills and various elements are included under this label. The diversification process occurs somehow naturally if Chell's (2013) approach is taken into account. According to this, the entrepreneurial skills are multi-dimensional and combine know-how, emotions and behavior. In other words, they are a complex set of rational, emotional and spiritual knowledge. Any combination of this kind that fosters innovation and value creation can be labeled as "entrepreneurial skills".

On the other hand, Chell's (2013) definition suits the mission of any higher education institution that aims to develop students' knowledge and to teach them how to act and react under certain circumstances. Thus, the higher education institution acts as a knowledge incubator; it provides a controlled and safe environment in which students can discover and develop their characteristics, acquire new knowledge, feel the "taste" of a challenge/success/failure, understand themselves and others, and improve their creativity, autonomy, and responsibility. 
Table 1. Entrepreneurial skills, a theoretical perspective

\begin{tabular}{|c|c|}
\hline $\begin{array}{l}\text { Entrepreneurial } \\
\text { skills }\end{array}$ & Author/-s (year) \\
\hline Performance & Athayde (2009); Chiru, Tachiciu, and Ciuchete (2012); \\
\hline & $\begin{array}{l}\text { Cunningham (1991); Draycott and Rae (2011); Gibb (2002); Lans, } \\
\text { Verstegen, and Mulder (2011); Mitchelmore and Rowley (2010); } \\
\text { Moberg et al. (2014); Morris, Webb. Fu, and Singhal (2013). }\end{array}$ \\
\hline Creativity & Athayde (2009); Chang and Rieple (2013); Cunningham (1991); \\
\hline & $\begin{array}{l}\text { Draycott and Rae (2011); Draycott, Rae and Vause (2011); Gibb } \\
\text { (2002); Hodzic (2016); Lans et al. (2011); Mitchelmore and } \\
\text { Rowley (2010); Moberg et al. (2014); Morris et al. (2013); Tiwari } \\
\text { (2011). }\end{array}$ \\
\hline Taking initiative & $\begin{array}{l}\text { Cui, Sun, Xiao, and Zhao (2016); Draycott and Rae (2011); Gibb } \\
\text { (2002); Hodzic (2016); Mitchelmore and Rowley (2010); Moberg } \\
\text { et al. (2014); Morris et al. (2013). }\end{array}$ \\
\hline Risk-taking & Covin and Wales (2012); Cui et al. (2016); Cunningham (1991); \\
\hline & $\begin{array}{l}\text { Draycott et al. (2011); Gibb (2002); Moberg et al. (2014); Morris } \\
\text { et al. (2013); Taatila and Down (2012). }\end{array}$ \\
\hline Perseverance & Gibb (2002); Hodzic (2016); Lans et al. (2011); Mitchelmore and \\
\hline & \\
\hline Leadership & $\begin{array}{l}\text { Athayde (2009); Chang and Rieple (2013); Cunningham (1991); } \\
\text { Draycott and Rae (2011); Draycott et al. (2011); Gibb (2002); } \\
\text { Lans et al. (2011); Man (2012); Mitchelmore and Rowley (2010); } \\
\text { Moberg et al. (2014); Morris et al. (2013); Schelfhout, Dochy, and } \\
\text { Janssens (2004). }\end{array}$ \\
\hline Communication & $\begin{array}{l}\text { Chang and Rieple (2013); Draycott and Rae (2011); Gibb (2002); } \\
\text { Hodzic (2016); Mitchelmore and Rowley (2010); Moberg et al. } \\
\text { (2014); Morris et al. (2013); Schelfhout et al. (2004); Taatila and } \\
\text { Down (2012). }\end{array}$ \\
\hline Problem solving & $\begin{array}{l}\text { Chang and Rieple (2013); Chiru et al. (2012); Cunningham (1991); } \\
\text { Draycott and Rae (2011); Gibb (2002); Hodzic (2016); Lans et al. } \\
\text { (2011); Mitchelmore and Rowley (2010); Moberg et al. (2014); } \\
\text { Morris et al. (2013); Schelfhout et al. (2004). }\end{array}$ \\
\hline Collaboratic & Chiru et al. (2012); Draycott and Rae (2011); Draycott et al. \\
\hline & $\begin{array}{l}\text { D11); Hodzic (2016); Mitchelmore and Rowley (2010); Moberg } \\
\text { al. (2014); Morris et al. (2013); Schelfhout et al. (2004). }\end{array}$ \\
\hline Learning & $\begin{array}{l}\text { Chang and Rieple (2013); Cunningham (1991); Draycott et al. } \\
\text { (2011); Gibb (2002); Hodzic (2016); Lans et al. (2011); Man } \\
\text { (2012); Mitchelmore and Rowley (2010); Moberg et al. (2014); } \\
\text { Morris et al. (2013); Schelfhout et al. (2004). }\end{array}$ \\
\hline Time & $\begin{array}{l}\text { Chell (2008); Frese (2007); Schenkel et al. (2009); Zahra et al. } \\
\text { (2006). }\end{array}$ \\
\hline
\end{tabular}

Each of these characterizes an entrepreneur - the owner of a company or the person who displays enterprising behavior (Gibb, 2002). 
Since a university's mission is somehow linked to entrepreneurship, the academic programs have three different ways of approaching the issue, namely: "about", "for" and "through" entrepreneurship (Gibb, 2002; Pittaway \& Edwards, 2012). The first ones are more traditional and adopt a theoretical perspective; they focus on delivering knowledge about what entrepreneurship is and how an entrepreneur should behave (Pittaway \& Edwards, 2012). Thus, they foster students' cognitive competences. The second ones are learner-centered and process-based, and try to combine theoretical and practical approaches; they concentrate on content and entrepreneurial skills, and support the development of both cognitive and functional competences. The last ones have a more pedagogical orientation and exploit the value of experiential learning; they aim to foster students' non-cognitive entrepreneurial skills (Moberg, 2014).

Still, Ahmad (2015) states that the current education programs are too mechanistic to encourage entrepreneurial behavior despite the fact that most researchers (Fayolle, 2013; Gibb, 2002) sustain that the last two perspectives from which entrepreneurial education is approached are the most effective ones. The former takes mainly into account the educational programs "about entrepreneurship" while the latter focuses on the programs which are based on active learning. According to Bonwell and Eison (1991), these involve using teaching methods such as teamwork, problem solving, case studies, simulations, role playing, and field work.

However, Leon (2015) proves that cultural specificity influences educators' choices for a specific teaching activity. Starting from Hofstede's traditional dimensions, it is demonstrated that there is a strong relationship between the cultural dimensions and the use of theoretical activities. According to Leon (2015, p. 687), "the log-odds of using theoretical activities within the courses will increase by 3.280 times (if masculinity increases with one unit), by 3.232 times (if uncertainty avoidance is augmented with one unit), and by 0.584 times (if the level of power distance is increased with one unit)". Synthesizing, the activities that are used during the courses define students' future skills and depend on cultural specificity.

Given the fact that cultural specificity represents "a pattern characterized by shared beliefs, attitudes, norms, roles and values that are organized around a theme and that can be found in certain geographic regions during a particular historic period" (Triandis, 1995, p. 43), and defines how people think, act, and react under certain circumstances, its influence upon the entrepreneurial skills development should be taken into consideration. Although various models are developed in order to measure and understand cultural specificity (Hall, 1981; House, Hanges, Javidan, Dorfman \& Gupta, 2004; Kluckhohn \& Strodbeck, 1961; Trompenaars, 1993), Hofstede's (2001) dimensions 
remain the cornerstone of intercultural management; these include: power distance (PD), individualism/collectivism, masculinity/femininity, uncertainty avoidance (UA), long term orientation (LTO), and indulgence.

Power distance (PD) concentrates on people's ability to accept how authority and control are distributed among the members of a society (Hofstede, 2001). It emphasizes individuals' preoccupation for formal or informal authority, status-seeking, privileges, and obedience. Therefore, in a high power distance society, there is a clear demarcation between those who are in charge and subordinates, the focus is on formal authority and privileges, and orders are executed, not discussed. On the other hand, in a low power distance culture, the informal authority is the one that matters and is given by individual's competencies not social status. From an educational point of view, these elements have the power to inhibit the development of students' estimating capacity and ICT skills (Leon, 2015). Most of the people who come from a high power distance society think that they do not need to forecast future events since they are not the ones who call the shots; they are taught how to do things and not to think of what should be done.

Individualism/collectivism bring forward who matters the most: the individual or the group (Hofstede, 2001). In an individualistic society, one speaks for himself/herself and is responsible for his/her destiny. Therefore, individualism fosters the development of students' written and oral communication skills (Leon, 2015). On the other hand, in a collectivistic society, responsibility is divided among the members and individuals are always looking for moral support and loyalty.

Masculinity / Femininity highlights whether the members of a society value more personal achievement or quality of life (Hofstede, 2001). In the first case, people are oriented towards success, material possessions and proactivity while, in the second case, special attention is given to personal relationships, spiritual possessions and the balance between work and family time. So far, it has been proven that masculinity inhibits the development of students' oral communication skills (Leon, 2015).

Uncertainty avoidance (UA) reflects people's tolerance to mistakes and unexpected situations (Hofstede, 2001). The cultures that have a high level of uncertainty avoidance encourage perfection and reject everything that does not follow the general standards or challenges the status-quo. On the other hand, the cultures that have a low level of uncertainty avoidance understand that making mistakes is part of the learning process, and support innovation and experimentation. As a consequence, uncertainty avoidance tends to foster the development of students' ICT skills and estimating capacity (Leon, 2015).

Long/short term orientation measures individuals' perspectives on time and their connection with the past (Hofstede, 2001). The persons who come 
from a culture characterized by long term orientation favor hard work, value their roots, and are capable of sacrificing present for future benefits. On the other hand, those who belong to a culture characterized by short term orientation act based on the "here and now" principle. Within this framework, long term orientation inhibits students' written and oral communication skills and boosts the development of their learning and ICT skills (Leon, 2015).

Indulgence sheds light on individuals' attitudes towards the gratification of needs and life (Itim International, 2017). Those who come from an indulgent culture favor the gratification of needs, personal well-being, thinking outside of the box, enjoying life, having fun and going beyond the limits. Those who belong to a restraint society suppress the gratification of needs, value the strict social norms and support maintaining the status-quo.

Against this backdrop, several gaps are identified in the entrepreneurship literature. Firstly, there is nogeneral accepted framework on the entrepreneurial skills that a university should develop among its graduates. The studies written so far present an ideal image and avoid pointing out the concrete characteristics of a higher education graduate, from an entrepreneurship perspective. Secondly, when it comes to teaching methods, an extensive list of techniques which support active learning is promoted. However, there is no prior research regarding their use in higher education institutions and their contribution to the development of students' entrepreneurial skills. Last but not least, none of the previously developed researches analyzes the influence that cultural specificity has on the development of entrepreneurial skills, in the higher education institutions. These gaps are filled by the current research.

\section{RESEARCH METHODS}

This research aims to determine how the economic and business administration faculties from within the European Union member states are contributing to the development of their students' entrepreneurial skills. Therefore, the following research objectives are pursued: (i) to identify the most important business schools from the European Union member states; (ii) to analyze their syllabuses; (iii) to determine the entrepreneurial skills that the graduates are assumed to possess, according to the academic curricula; (iv) to analyze the compatibility between the skills developed during the bachelor studies and the "classical" entrepreneurial skills; (v) to analyze how the entrepreneurial skills that the business schools aim to develop among the future human resources affect a country's capacity to be a best performer, based on the Entrepreneurship Development Index; and (vi) to determine the influence that cultural specificity has on developing students' entrepreneurial skills. 
Table 2. Selection criteria

\begin{tabular}{lll}
\hline Criterion & Reference level & Units of analysis \\
\hline Presence in the QS Worlds University & Present & 293 \\
Rankings & $>12.000$ students & 226 \\
Number of students & High & 185 \\
Research level & $>25$ years & 182 \\
Experience on the educational services & & \\
market & First & 24 \\
Position occupied in national ranking & Syllabus in English & 21 \\
Access to information & &
\end{tabular}

Source: Leon (2014).

Further, a case study strategy is employed which concentrates on the most important business schools from within the European Union member states. This domain is chosen due to the fact that their graduates are going to work in the most dynamic economic sectors, namely: banking, commerce, business administration, tourism etc. (Leon, 2016). Following the same methodology as Leon (2014), the best business school from each European Union member state is selected. The selection criteria are: (i) presence in the QS Worlds University Rankings; (ii) number of students; (iii) research level; (iv) experience in the educational services market; (v) position occupied in national ranking; and (vi) access to information (Table 2). In the end, 21 business schools are selected and analyzed (Table 3).

Table 3. Case study units

\begin{tabular}{llll}
\hline No. & University & No. & University \\
\hline 1 & University of Vienna & 12 & Trinity College Dublin \\
2 & Katholieke Universiteit Leuven & 13 & University of Bologna \\
\hline 3 & University of St. Kliment Ohridski & 14 & University of Latvia \\
4 & University of Zagreb & 15 & Vilnius University \\
5 & Charles University & 16 & University of Amsterdam \\
6 & Aarhus University & 17 & University of Coimbra \\
7 & University of Tartu & 18 & University of Ljubljana \\
8 & Ecole normale supérieure, Paris & 19 & Universitat Autónoma de Barcelona \\
9 & Technische Universität München & 20 & University of Cambridge \\
10 & University of Crete & 21 & Alexandru loan Cuza University \\
11 & University of Szeged & & \\
\hline
\end{tabular}

In the second stage, for each of the selected higher education institutions, the courses taught at undergraduate level are identified. Then, 267 
syllabuses are identified and analyzed. To each of them a content analysis is applied; the units of analysis are represented by educational goals, practical assignments, and teaching methods (Leon, 2016). The analysis focuses on the main sections of the syllabuses and does not take into account the hours dedicated to each subject.

Based on the literature review, it is assumed that the main entrepreneurial skills that students should achieve by the end of the undergraduate studies are: (i) performance orientation (Athayde, 2009; Chiru et al., 2012; Cunningham, 1991; Draycott \& Rae, 2011; Gibb, 2002; Lans et al., 2011; Mitchelmore \& Rowley, 2010; Moberg et al., 2014; Morris et al., 2013); (ii) creativity (Athayde, 2009; Chang \& Rieple, 2013; Cunningham, 1991; Draycott \& Rae, 2011; Draycott et al., 2011; Gibb, 2002; Hodzic, 2016; Lans et al., 2011; Mitchelmore \& Rowley, 2010; Moberg et al., 2014; Morris et al., 2013; Tiwari, 2011); (iii) taking the initiative (Cui et al., 2016; Draycott \& Rae, 2011; Gibb, 2002; Hodzic, 2016; Mitchelmore \& Rowley, 2010; Moberg et al., 2014; Morris et al., 2013); (iv) risk-taking (Covin \& Wales, 2012; Cui et al., 2016; Cunningham, 1991; Draycott et al., 2011; Gibb, 2002; Moberg et al., 2014; Morris et al., 2013; Taatila \& Down, 2012); (v) perseverance (Gibb, 2002; Hodzic, 2016; Lans et al., 2011; Mitchelmore \& Rowley, 2010; Moberg et al., 2014); (vi) leadership (Athayde, 2009; Chang \& Rieple, 2013; Cunningham, 1991; Draycott \& Rae, 2011; Draycott et al., 2011; Gibb, 2002; Lans et al., 2011; Man, 2012; Mitchelmore \& Rowley, 2010; Moberg et al., 2014; Morris et al., 2013; Schelfhout et al., 2004); (vii) communication (Chang \& Rieple, 2013; Draycott \& Rae, 2011; Gibb, 2002; Hodzic, 2016; Mitchelmore \& Rowley, 2010; Moberg et al., 2014; Morris et al., 2013; Schelfhout et al., 2004; Taatila \& Down, 2012); (viii) problem solving (Chang \& Rieple, 2013; Chiru et al., 2012; Cunningham, 1991; Draycott \& Rae, 2011; Gibb, 2002; Hodzic, 2016; Lans et al., 2011; Mitchelmore \& Rowley, 2010; Moberg et al., 2014; Morris et al., 2013; Schelfhout et al., 2004); (ix) collaboration / teamwork (Chiru et al., 2012; Draycott \& Rae, 2011; Draycott et al., 2011; Hodzic, 2016; Mitchelmore \& Rowley, 2010; Moberg et al., 2014; Morris et al., 2013; Schelfhout et al., 2004); (x) learning skills (Chang \& Rieple, 2013; Cunningham, 1991; Draycott et al., 2011; Gibb, 2002; Hodzic, 2016; Lans et al., 2011; Man, 2012; Mitchelmore \& Rowley, 2010; Moberg et al., 2014; Morris et al., 2013; Schelfhout et al., 2004); and (xi) time management skills (Chell, 2008; Frese, 2007; Schenkel et al., 2009; Zahra et al., 2006).

In the third phase, a multinomial logistic regression is employed in order to establish how the entrepreneurial skills that the business schools aim to develop among the future human resources affect a country's capacity to be among the best performers. This technique is chosen due to the fact that: (i) it is more robust to violations of assumptions of multivariate normality; 
(ii) it does not assume a linear relationship between the dependent and independent variables; (iii) independent variables are not necessarily unbounded; and (iv) normally distributed errors terms are not assumed (Bayaga, 2010; Tabachnick, Fidell \& Osterlind, 2001). Therefore, at this level, the focus is on predicting a nominal dependent variable (country's capacity to be among the best performers) based on more continuous independent variables (entrepreneurial skills). Practically, the nominal dependent variable is determined based on the Global Entrepreneurship Index (Acs, Szerb \& Autio, 2017) while the continuous independent variables are represented by the entrepreneurial skills, identified in the previous stage.

Last but not least, theattention switchesfrom the effects of entrepreneurial skills development to the factors that may influence it. Therefore, Poisson regression is applied; this is a generalized linear model which: (i) describes the transformations of the conditional mean of the dependent variable; (ii) allows the dependent variable to have conditional distributions other than the normal; and (iii) uses numerical and categorical explanatory variables (Hoffman, 2004; Moksony \& Hegedus, 2014). Thus, the dependent variable is represented by each of the previously identified entrepreneurial skills while the independent variable is represented by Hofstede's cultural dimensions, namely: power distance (PD), individualism / collectivism, masculinity / femininity, uncertainty avoidance (UA), long / short term orientation (LTO), and indulgence (Itim International, 2017).

\section{ANALYSIS/STUDY}

As it can be noticed from Figure 1, most of the educational programs aim to develop students' functional competences by making sure they acquire specialized knowledge. Although the analyzed business schools remain faithful to the traditional mission of a university - providing the needed knowledge for individuals' and society's development -, they are also trying to adapt their curricula to labor market demands and to foster skills development. Therefore, they boost the improvement of several entrepreneurial skills, namely: learning, problem solving, risk-taking, time management, oral and written communication, and teamwork skills. These are supposed to facilitate the identification and exploitation of various opportunities. Thus, in light of these, the graduates will be able to recognize various sources of opportunities, to solve complex problems, to expose themselves to an uncertain environment, to meet deadlines, to communicate and collaborate with others, and to learn from experience and from others. 


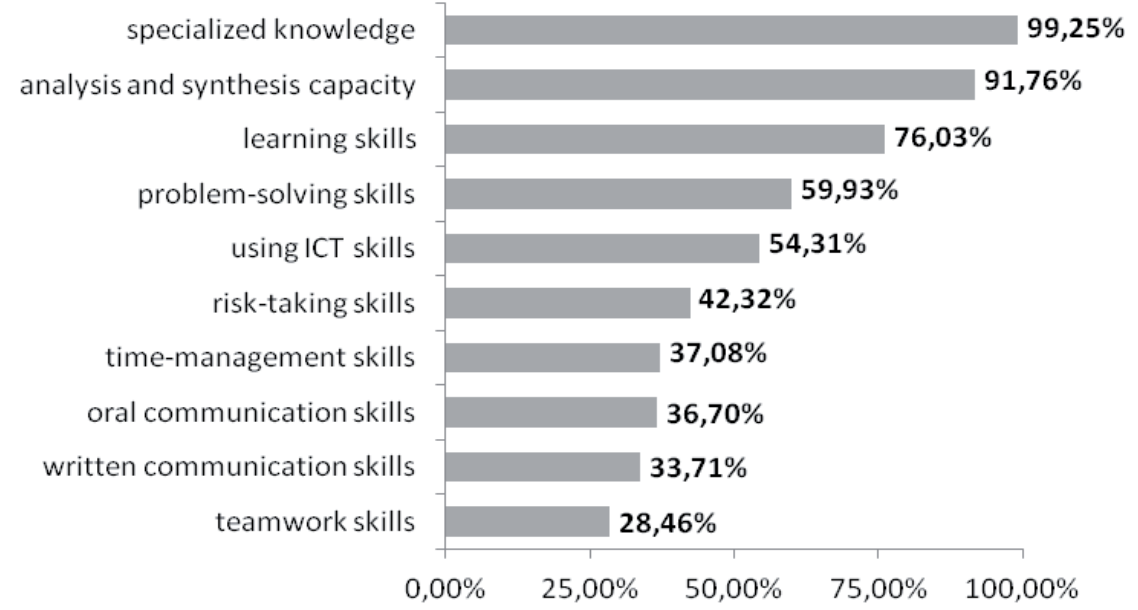

Figure 1. The skills which the courses taught at undergraduate level focus on

Source: Leon (2016).

Nevertheless, the European business schools take into account the challenges that occur in the business environment and on the labor market. Therefore, almost $54.31 \%$ of the analyzed syllabuses shed light on the importance of knowing how to use ICTs. On the one hand, this comes in line with a company's dependence on technology, and on the other hand, it exploits Millennials predisposition of being connected through ICTs. If the elements presented in the previous section are taken into consideration, it can be argued that these skills were neglected by the entrepreneurial studies which have been developed so far; however, they were not neglected by the European educational programs.

The development of these skills is ensured by combining passive and active learning (Figure 2). Although most courses (98.88\%) still have their roots in a traditional and theoretical perspective, much progress has been made as more than $50 \%$ of the courses use active learning methods. Case studies, problem solving activities and discussions are frequently used within the programs. This emphasizes a slow transition from "about entrepreneurship" to "for entrepreneurship" educational programs. In other words, the European economic and business administration faculties have started to switch from a theoretical approach to a more complex one that combines theory with practice. As a consequence, they will continue to provide wellqualified human resources to the labor market. However, there is still a lot to do since they are far from using experiential learning and simulations. 


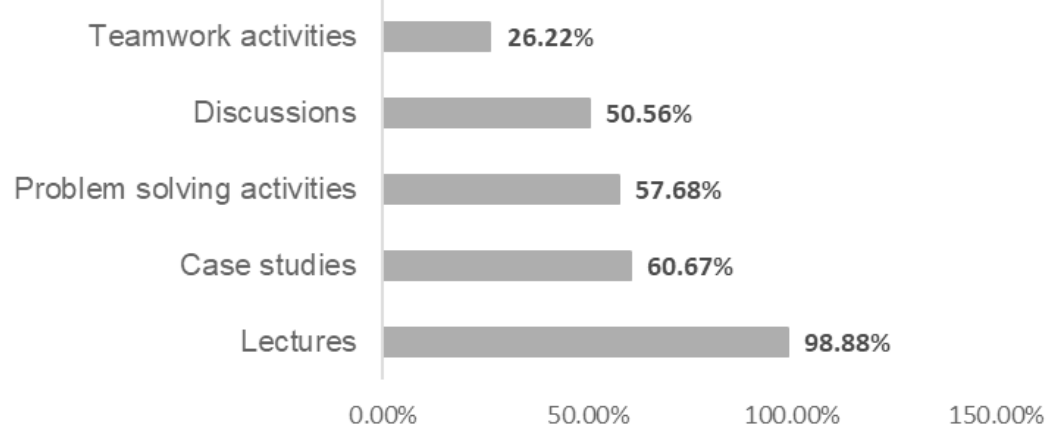

Figure 2. The teaching methods that are frequently used in the European higher education institutions

Source: Leon (2016).

According to the data presented in Table 4, the European business schools manage to develop most of the required entrepreneurial skills. Their graduates are both task and people oriented. On the one hand, they value performance, are capable of solving problems and taking calculated risks. On the other hand, they know how to communicate and collaborate within a team. However, their entrepreneurial skills are more appropriate for an enterprising employee than for a business owner. In order to complete the demands for the second approach, the higher education programs should encourage their students to be creative, perseverant, and to take the initiative. In other words, they have to challenge their mental models, and to teach them how to think outside of the box and to stand up for their beliefs.

As aforementioned, the European business schools use active learning for developing students' entrepreneurial skills. Within the bachelor programs, they focus on improving cognitive, functional, and behavioral competences by combining lectures with active learning techniques (problem solving, teamwork, discussions, and case studies). Nevertheless, it may be stated that their programs are combining an "about entrepreneurship" with a "for entrepreneurship" perspective. However, further attention should be offered to a "through entrepreneurship" approach which involves using experiential learning and simulations; so far, none of the analyzed educational programs take these teaching methods into account. Therefore, their graduates lack creativity, initiative and perseverance. 
Table 4. Comparative analysis between the required entrepreneurial skills and those developed among the business schools' graduates

\begin{tabular}{lll}
\hline Entrepreneurial skills & Required & Developed \\
\hline Performance orientation & + & + \\
Creativity & + & - \\
Taking the initiative & + & - \\
Risk-taking & + & + \\
Perseverance & + & - \\
Leadership & + & - \\
Communication & + & + \\
Problem solving & + & + \\
Collaboration / Teamwork & + & + \\
Learning & + & + \\
Time management & + & + \\
\hline
\end{tabular}

This situation has effects not only at the individual and organizational level but also at the national level. In order to determine the impact that the development of the current entrepreneurial skills have on the national entrepreneurship phenomena, multinomial logistic regression is employed. Thus, a country's capacity to be among the top performers is the dependent variable, while the independent variables are considered to be risk-taking, communication, problem solving, teamwork, performance orientation, and time management skills. Since the Pearson Chi-Square value is small (Table 5) and the $p$-value is not statistically significant $(p=0.091>0.05)$ then it can be argued that the model fits the data well.

Table 5. Multinomial logistic regression between the skills developed within the European business schools and entrepreneurship development. Goodness of fit

\begin{tabular}{llll}
\hline & Chi-Square & df & Sig. \\
\hline Pearson & 21.436 & 14 & .091 \\
Deviance & 13.635 & 14 & .477 \\
\hline
\end{tabular}

The assumption is confirmed also by data presented in Table 6 which analyzes whether the variables included in the model are statistically improving the prediction of the dependent variable or not. Given the fact that $p=0.017<0.05$, it can be stated that the skills developed within the European business schools are influencing countries' capacity to be among the top performers when it comes to entrepreneurship development. 
Table 6. Multinomial logistic regression between the skills developed within the European business schools and entrepreneurship development. Model fitting

\begin{tabular}{lllll}
\hline \multirow{2}{*}{ Model } & \multicolumn{2}{l}{$\begin{array}{l}\text { Model fitting criteria } \\
\text {-2 Log likelihood }\end{array}$} & \multicolumn{2}{l}{ Likelihood ratio tests } \\
Chi-square & df & Sig. \\
\hline Intercept & 29.065 & & & \\
$\begin{array}{l}\text { Only } \\
\text { Final }\end{array}$ & 13.635 & 15.430 & 6 & .017 \\
\hline
\end{tabular}

The influence that each variable has on a country's capacity to be among the best performers is presented in Table 7. This shows that all six independent variables are statistically significant $(p<0.05)$.

Table 7. Multinomial logistic regression between the skills developed within the European business schools and entrepreneurship development. Likelihood ratio tests

\begin{tabular}{lllll}
\hline \multirow{2}{*}{ Effect } & \multicolumn{3}{l}{ Model fitting criteria } & \multicolumn{3}{l}{ Likelihood ratio tests } \\
\cline { 2 - 5 } & $\begin{array}{l}\mathbf{- 2} \text { Log likelihood of reduced } \\
\text { model }\end{array}$ & Chi-square & df & Sig. \\
\hline Intercept & 19.026 & 5.392 & 1 & .020 \\
Risk-taking & 13.703 & .068 & 1 & .047 \\
Communication & 13.636 & .001 & 1 & .007 \\
Problem-solving & 27.786 & 14.152 & 1 & .000 \\
Teamwork & 16.644 & 3.009 & 1 & .038 \\
Performance & 16.487 & 2.852 & 1 & .019 \\
orientation & & & & \\
\hline Time management & 13.683 & .049 & 1 & .026 \\
\hline
\end{tabular}

Note: The chi-square statistic is the difference in -2 log-likelihoods between the final model and a reduced model. The reduced model is formed by omitting an effect from the final model. The null hypothesis is that all parameters of that effect are 0 .

The previous analysis brings forward the effects that entrepreneurial education has on the development of the national economy. However, it is restricted by various economic, social, demographic and cultural factors. Within this framework, special attention is given to cultural specificity which has the power to shape what people think, feel and do.

Table 8. Poisson regression between entrepreneurial skills development and Hofstede's cultural dimensions. Omnibus test

\begin{tabular}{llcl}
\hline Dependent variable & Likelihood ratio Chi-square & df & Sig. \\
\hline Risk-taking skills & 13.012 & 6 & .043 \\
Communication skills & 11.218 & 6 & .028 \\
\hline
\end{tabular}




\begin{tabular}{llll}
\hline Dependent variable & Likelihood ratio Chi-square & df & Sig. \\
\hline Problem-solving skills & 3.600 & 6 & .031 \\
Teamwork & 11.490 & 6 & .047 \\
Performance orientation & 2.533 & 6 & .065 \\
Time management skills & 9.022 & 6 & .017 \\
\hline
\end{tabular}

Notes: Dependent variable: risk-taking.

Model: (Intercept), PD, Individualism, Masculinity, UA, LTO, Indulgence.

a. Compares the fitted model against the intercept-only model.

In order to test the influence of cultural specificity on entrepreneurial skills development, Poisson regression is employed. Firstly, the analysis aims to determine whether entrepreneurial skills development is subject to Hofstede's (2001) cultural dimensions or not. Based on the data presented in Table 8, it can be stated that, in most of the cases, the independent variables (Hofstede's cultural dimensions) collectively improve the model over the intercept-only model. In other words, since the $p$-value is smaller than 0.05 , the overall model is statistically significant for entrepreneurial skills development. The only exception is represented by the development of performance orientation skills where $p=0.065$. When it comes to developing the risk-taking skills, not all the independent variables are statistically significant. According to the $p$-value presented in Table 9, three cultural dimensions should be taken into consideration, namely: uncertainty avoidance $(p=0.045)$, long term orientation $(p=0.035)$, and indulgence $(p=0.008)$.

Table 9. Poisson regression between the development of the risk-taking skills and Hofstede's cultural dimensions. Test of model effects

\begin{tabular}{|c|c|c|c|c|}
\hline \multirow[t]{2}{*}{ Source } & \multirow[b]{2}{*}{ Wald Chi-square } & \multicolumn{2}{|l|}{ Type III } & \\
\hline & & df & Sig. & \\
\hline (Intercept) & & 20.027 & 1 & .000 \\
\hline PD & & .984 & 1 & .321 \\
\hline Individualism & & .375 & 1 & .540 \\
\hline Masculinity & & .161 & 1 & .689 \\
\hline UA & & .038 & 1 & .045 \\
\hline LTO & & & & .035 \\
\hline 3.736 & & & & \\
\hline 1 & & & & \\
\hline Indulgence & & 6.957 & 1 & .008 \\
\hline
\end{tabular}

Notes: Dependent variable: risk-taking.

Model: (Intercept), PD, Individualism, Masculinity, UA, LTO, Indulgence. 
The effect that each of them has on the development of the risk-taking skills is presented in Table 10.

Table 10. Poisson regression between the development of the risk-taking skills and Hofstede's cultural dimensions. Parameter estimates

\begin{tabular}{|c|c|c|c|c|c|c|c|c|c|c|}
\hline \multirow[t]{2}{*}{ Parameter } & \multirow[t]{2}{*}{ B } & \multirow[t]{2}{*}{$\begin{array}{l}\text { Std. } \\
\text { error }\end{array}$} & \multicolumn{2}{|c|}{$\begin{array}{l}95 \% \text { Wald } \\
\text { confidence } \\
\text { interval }\end{array}$} & \multicolumn{3}{|c|}{ Hypothesis test } & \multirow[t]{2}{*}{$\operatorname{Exp}(B)$} & \multicolumn{2}{|c|}{$\begin{array}{l}\text { 95\% Wald } \\
\text { confidence } \\
\text { interval for } \\
\text { Exp(B) }\end{array}$} \\
\hline & & & Lower & Upper & $\begin{array}{l}\text { Wald Chi- } \\
\text { square }\end{array}$ & df & Sig. & & Lower & Upper \\
\hline (Intercept) & 2.270 & .5072 & 1.276 & 3.264 & 20.027 & 1 & .885 & 9.677 & 3.581 & 26.148 \\
\hline PD & -.286 & .2886 & -.852 & .279 & .984 & 1 & .321 & .751 & .427 & 1.322 \\
\hline Individualism & .227 & .3703 & -.499 & .953 & .375 & 1 & .540 & 1.255 & .607 & 2.592 \\
\hline Masculinity & -.084 & .2093 & -.494 & .326 & .161 & 1 & .689 & .920 & .610 & 1.386 \\
\hline UA & .091 & .4631 & -.817 & .998 & .038 & 1 & .045 & 1.095 & .442 & 2.713 \\
\hline LTO & -.587 & .3039 & -1.183 & .008 & 3.736 & 1 & .035 & .556 & .306 & 1.008 \\
\hline Indulgence & -.820 & .3108 & -1.429 & -.211 & 6.957 & 1 & .008 & .441 & .240 & .810 \\
\hline (Scale) & $1 a$ & & & & & & & & & \\
\hline
\end{tabular}

Notes: Dependent variable: risk-taking.

Model: (Intercept), PD, Individualism, Masculinity, UA, LTO, Indulgence.

So, within this framework, uncertainty avoidance (UA) has the most powerful influence on the development of risk-taking skills; its exponential value is 1.095. Long term orientation (LTO) is in second place with a 0.556 exponential value while indulgence is third (exponential value equals 0.441 ).

If communication skills are taken into consideration, it can be observed that they depend on masculinity and indulgence (Table 11). The former has an exponential value of 0.726 while the latter has an exponential value of 1.585. So, there is a $58.5 \%$ increase in the development of communication skills for each step that takes society closer to an indulgent one.

Table 11. Poisson regression between the development of the communication skills and Hofstede's cultural dimensions. Parameter estimates

\begin{tabular}{|c|c|c|c|c|c|c|c|}
\hline \multirow[t]{2}{*}{ Parameter } & \multirow[t]{2}{*}{ B } & \multirow{2}{*}{$\begin{array}{l}\text { Std. } \\
\text { error }\end{array}$} & $\begin{array}{l}\text { 95\% Wald } \\
\text { confidence } \\
\text { interval }\end{array}$ & Hypothesi & test & \multirow{2}{*}{$\operatorname{Exp}(B)$} & \multirow{2}{*}{$\begin{array}{l}\text { 95\% Wald } \\
\text { confidence } \\
\text { interval for } \\
\text { Exp(B) } \\
\text { Lower Upper }\end{array}$} \\
\hline & & & Lower Upper & $\begin{array}{l}\text { Wald } \\
\text { Chi- df } \\
\text { square }\end{array}$ & Sig. & & \\
\hline (Intercept) & 1.231 & .4647 & $.321 \quad 2.142$ & 7.0211 & .180 & 3.426 & $\begin{array}{ll}1.378 & 8.517\end{array}$ \\
\hline
\end{tabular}




\begin{tabular}{|c|c|c|c|c|c|c|c|c|c|c|}
\hline \multirow[t]{3}{*}{ Parameter } & \multirow[t]{3}{*}{ B } & \multirow{3}{*}{$\begin{array}{l}\text { Std. } \\
\text { error }\end{array}$} & \multicolumn{2}{|c|}{$\begin{array}{l}\text { 95\% Wald } \\
\text { confidence } \\
\text { interval }\end{array}$} & \multicolumn{3}{|c|}{ Hypothesis test } & \multirow[t]{3}{*}{$\operatorname{Exp}(B)$} & \multicolumn{2}{|c|}{$\begin{array}{l}\text { 95\% Wald } \\
\text { confidence } \\
\text { interval for } \\
\text { Exp(B) }\end{array}$} \\
\hline & & & & & Wald & & & & & \\
\hline & & & Lower & Upper & $\begin{array}{l}\text { Chi- } \\
\text { square }\end{array}$ & df & Sig. & & Lowe & Uppe \\
\hline PD & .192 & .3198 & -.435 & .818 & .359 & 1 & .549 & 1.211 & .647 & 2.267 \\
\hline Individualism & .250 & .3973 & -.529 & 1.028 & .395 & 1 & .530 & 1.283 & .589 & 2.796 \\
\hline Masculinity & -.320 & .2387 & -.788 & .148 & 1.796 & 1 & .008 & .726 & .455 & 1.159 \\
\hline UA & .411 & .4194 & -.411 & 1.233 & .959 & 1 & .327 & 1.508 & .663 & 3.431 \\
\hline LTO & -.532 & .3204 & -1.160 & .096 & 2.755 & 1 & .097 & .587 & .313 & 1.101 \\
\hline Indulgence & .460 & .2443 & -.018 & .939 & 3.552 & 1 & .025 & 1.585 & .982 & 2.558 \\
\hline (Scale) & $1 a$ & & & & & & & & & \\
\hline
\end{tabular}

Notes: Dependent variable: communication.

Model: (Intercept), PD, Individualism, Masculinity, UA, LTO, Indulgence.

a. Fixed at the displayed value.

Moreover, the development of problem solving skills is also a subject of cultural specificity (Table 12). At this level, only three cultural dimensions are statistically significant, namely: individualism $(p=0.034)$, masculinity ( $p$ $=0.008)$, and long term orientation $(p=0.031)$. Masculinity has the highest exponential value (1.028) while individualism has the lowest exponential value (0.831).

Table 12. Poisson regression between the development of the problem solving skills and Hofstede's cultural dimensions. Parameter estimates

\begin{tabular}{|c|c|c|c|c|c|c|c|c|c|c|}
\hline \multirow[t]{2}{*}{ Parameter } & \multirow[t]{2}{*}{ B } & \multirow[t]{2}{*}{$\begin{array}{l}\text { Std. } \\
\text { error }\end{array}$} & \multicolumn{2}{|c|}{$\begin{array}{l}\text { 95\% Wald } \\
\text { confidence } \\
\text { interval }\end{array}$} & \multicolumn{3}{|c|}{ Hypothesis Test } & \multirow[t]{2}{*}{$\operatorname{Exp}(B)$} & \multicolumn{2}{|c|}{$\begin{array}{l}\text { 95\% Wald } \\
\text { confidence } \\
\text { interval for } \\
\text { Exp(B) }\end{array}$} \\
\hline & & & Lower & Upper & $\begin{array}{l}\text { Wald Chi- } \\
\text { square }\end{array}$ & df & Sig. & & Lower & Upper \\
\hline (Intercept) & 1.970 & .3767 & 1.232 & 2.709 & 27.361 & 1 & .881 & 7.173 & 3.428 & 15.010 \\
\hline PD & -.048 & .2426 & -.523 & .428 & .038 & 1 & .844 & .954 & .593 & 1.534 \\
\hline Individualism & -.185 & .2968 & -.766 & .397 & .387 & 1 & .034 & .831 & .465 & 1.488 \\
\hline Masculinity & .027 & .1834 & -.332 & .387 & .022 & 1 & .008 & 1.028 & .718 & 1.472 \\
\hline UA & .325 & .3393 & -.340 & .990 & .920 & 1 & .338 & 1.385 & .712 & 2.692 \\
\hline LTO & -.147 & .2351 & -.608 & .314 & .392 & 1 & .031 & .863 & .544 & 1.368 \\
\hline Indulgence & .035 & .2067 & -.370 & .440 & .028 & 1 & .867 & 1.035 & .690 & 1.552 \\
\hline (Scale) & $1 a$ & & & & & & & & & \\
\hline
\end{tabular}

Notes: Dependent variable: problem solving. 
Model: (Intercept), PD, Individualism, Masculinity, UA, LTO, Indulgence.

a. Fixed at the displayed value.

In addition, the development of teamwork skills is supported by three cultural dimensions (Table 13), namely: individualism ( $p=0.036$ ), masculinity $(p=0.005)$, and indulgence $(p=0.027)$. As can be noticed, individualism has an exponential value of 0.615 . On the other hand, masculinity and indulgence may generate an increase in the advancement of teamwork skills by $11.30 \%$ and $85.00 \%$ respectively.

Table 13. Poisson regression between the development of the teamwork skills and Hofstede's cultural dimensions. Parameter estimates

\begin{tabular}{|c|c|c|c|c|c|c|c|c|c|c|}
\hline \multirow[t]{2}{*}{ Parameter } & \multirow[t]{2}{*}{ B } & \multirow{2}{*}{$\begin{array}{l}\text { Std. } \\
\text { error }\end{array}$} & \multicolumn{2}{|c|}{$\begin{array}{l}95 \% \text { Wald } \\
\text { confidence } \\
\text { interval }\end{array}$} & \multicolumn{3}{|c|}{ Hypothesis test } & \multirow[t]{2}{*}{$\operatorname{Exp}(B)$} & \multicolumn{2}{|c|}{$\begin{array}{l}\text { 95\% Wald } \\
\text { confidence } \\
\text { interval for } \\
\text { Exp(B) }\end{array}$} \\
\hline & & & & & $\begin{array}{l}\text { Wald } \\
\text { Chi- }\end{array}$ & df & Sig. & & & Upper \\
\hline (Intercept) & 1.447 & .5184 & .431 & 2.463 & $\begin{array}{l}\text { square } \\
7.793\end{array}$ & 1 & .689 & 4.251 & 1.539 & 11.741 \\
\hline PD & -.195 & .3950 & -.969 & .580 & .243 & 1 & .622 & .823 & .380 & 1.785 \\
\hline Individualism & -.486 & .4741 & -1.415 & .444 & 1.049 & 1 & .036 & .615 & .243 & 1.559 \\
\hline Masculinity & .107 & .2669 & -.416 & .630 & .160 & 1 & .005 & 1.113 & .660 & 1.877 \\
\hline UA & .226 & .4362 & -.629 & 1.081 & .269 & 1 & .604 & 1.254 & .533 & 2.948 \\
\hline LTO & -.355 & .3370 & -1.016 & .305 & 1.112 & 1 & .292 & .701 & .362 & 1.357 \\
\hline Indulgence & .615 & .2787 & .069 & 1.161 & 4.875 & 1 & .027 & 1.850 & 1.072 & 3.194 \\
\hline (Scale) & $1 a$ & & & & & & & & & \\
\hline
\end{tabular}

Notes; Dependent variable: teamwork.

Model: (Intercept), PD, Individualism, Masculinity, UA, LTO, Indulgence.

a. Fixed at the displayed value.

Last but not least, an intercultural influence can be identified when it comes to developing students' time management skills (Table 14). This is influenced by uncertainty avoidance $(p=0.003)$ which has an exponential value of 1.702 . In other words, a $70.20 \%$ increase in the development of time management skills can appear if the uncertainty avoidance (UA) increases by one unit. 
Table 14. Poisson regression between the development of the time management skills and Hofstede's cultural dimensions. Parameter estimates

\begin{tabular}{|c|c|c|c|c|c|c|c|c|c|c|}
\hline \multirow[t]{3}{*}{ Parameter } & \multirow[t]{3}{*}{ B } & \multirow{3}{*}{$\begin{array}{l}\text { Std. } \\
\text { Error }\end{array}$} & \multicolumn{2}{|c|}{$\begin{array}{l}\text { 95\% Wald } \\
\text { confidence } \\
\text { interval }\end{array}$} & \multicolumn{3}{|c|}{ Hypothesis test } & \multirow[t]{3}{*}{ Exp(B) } & \multicolumn{2}{|c|}{$\begin{array}{l}\text { 95\% Wald } \\
\text { confidence } \\
\text { interval for } \\
\text { Exp(B) }\end{array}$} \\
\hline & & & & & Wald & & & & & \\
\hline & & & Lower & Upper & $\begin{array}{l}\text { Chi- } \\
\text { Square }\end{array}$ & df & Sig. & & Lower & Upper \\
\hline (Intercept) & 1.435 & .4892 & .476 & 2.393 & 8.599 & 1 & .212 & 4.198 & 1.609 & 10.950 \\
\hline PD & -.180 & .3332 & -.833 & .473 & .291 & 1 & .589 & .835 & .435 & 1.605 \\
\hline Individualism & -.557 & .3923 & -1.326 & .212 & 2.014 & 1 & .156 & .573 & .266 & 1.236 \\
\hline Masculinity & -.116 & .2428 & -.592 & .360 & .227 & 1 & .634 & .891 & .553 & 1.434 \\
\hline UA & .532 & .4263 & -.304 & 1.367 & 1.557 & 1 & .003 & 1.702 & .738 & 3.925 \\
\hline LTO & -.005 & .2889 & -.572 & .561 & .000 & 1 & .985 & .995 & .565 & 1.752 \\
\hline Indulgence & .403 & .2470 & -.081 & .888 & 2.669 & 1 & .102 & 1.497 & .923 & 2.429 \\
\hline (Scale) & $1 a$ & & & & & & & & & \\
\hline
\end{tabular}

Notes; Dependent variable: time management

Model: (Intercept), PD, Individualism, Masculinity, UA, LTO, Indulgence

a. Fixed at the displayed value.

\section{CONCLUSION}

Synthesizing, the research objectives were achieved since: (i) the most important business schools from the European Union member states were identified; (ii) their syllabuses were analyzed; (iii) the entrepreneurial skills that the graduates are assumed to possess, according to the academic curricula, were brought forward; (iv) the compatibility between the skills developed during the bachelor studies and the "classical" entrepreneurial skills was emphasized; (v) the effects that the entrepreneurial education will have on country's capacity to be among the best performers, in terms of entrepreneurship development, was highlighted; and (vi) the influence that cultural specificity has on entrepreneurial skills development was emphasized.

As was previously demonstrated, the top ranking European business schools tend to concentrate on using active learning when it comes to developing students' entrepreneurial skills. However, their bachelor programs combine an "about entrepreneurship" with a "for entrepreneurship" perspective, and neglect the importance of a "through entrepreneurship" approach. As a consequence, their graduates acquire several entrepreneurial skills (like, risktaking, performance orientation, problem solving, communication, teamwork, and time management) but they lack creativity, initiative and perseverance; 
the three of them make a practical difference between a top performer and a "regular" entrepreneur that tries to do everything by the book.

What happens in the educational sector has implications at a business and national level. So, based on the multinomial logistic regression, it can be stated that several entrepreneurial skills can predict whether a country has the capacity to be among the top performers, in terms of entrepreneurship development, or not. Six skills have the ability to do this, namely: risk-taking, communication, problem solving, teamwork, performance orientation, and time management.

Nevertheless, the development of the entrepreneurial skills through the educational programs of European business schools is also conditioned by the national cultural profile (Table 14); the only exception is represented by performance orientation skills. So, a country's level of individualism tends to have an impact on the development of students' problem solving skills while its orientation towards masculinity is reflected in the development of problem solving, communication, and teamwork skills. Furthermore, the societies which have a high level of uncertainty avoidance (UA) focus on risk-taking and time management. Nevertheless, long term orientation (LTO) encourages risk-taking and problem solving while indulgence strengthens risk-taking, communication and teamwork.

Table 15. The connections between the entrepreneurial skills and Hofstede's cultural dimensions

\begin{tabular}{|c|c|c|c|c|c|}
\hline $\begin{array}{l}\text { Hofstede's cultural } \\
\text { dimensions }\end{array}$ & $\begin{array}{l}\text { Risk- } \\
\text { taking }\end{array}$ & $\begin{array}{l}\text { Problem- } \\
\text { solving }\end{array}$ & Communication & Teamwork & $\begin{array}{l}\text { Time } \\
\text { management }\end{array}$ \\
\hline \multicolumn{6}{|l|}{$P D$} \\
\hline Individualism & & $x$ & & & \\
\hline Masculinity & & $x$ & $x$ & $x$ & \\
\hline UA & $x$ & & & & $x$ \\
\hline LTO & $x$ & $x$ & & & \\
\hline Indulgence & $x$ & & $x$ & $x$ & \\
\hline
\end{tabular}

These findings have both theoretical and practical implications. On a theoretical level, they extend the literature regarding entrepreneurial skills by providing concrete information on the skills which the academic curricula focus on. On a practical level, they provide valuable insights regarding the skills of future entrepreneurs; these will influence their behavior in the business environment no matter whether they will choose to be self-employed or employees. Besides, it brings forward the link between cultural specificity and entrepreneurial skills development, and the effects that the latter 
has on a country's capacity to be among the best performers, in terms of entrepreneurship development.

Despite these valuable insights, this research is limited by the fact that it only considers a reduced number of higher education institutions and it is based on what is written in the syllabuses. In other words, it reflects what is happening in the best economic and business administration faculties and it neglects what is happening in other institutions. In addition, it uses the syllabuses as a reference point which means that it actually describes the goals of the academic curricula and not necessarily its results. Last but not least, the hours dedicated to each subject and the time lag between the period of studies and the real employment of the graduates are not taken in consideration.

Starting from these, at least three further research directions can be identified, namely: (i) extending the research on a significant sample of European higher education institutions; (ii) measuring the entrepreneurial skills of European business schools' graduates; and (iii) analyzing the real entrepreneurial skills developed among the graduates.

\section{Acknowledgments}

This paper is a revised and expanded version of a paper entitled 'University - A Knowledge Incubator for Developing Entrepreneurial Skills', presented at the 1st edition of the Entrepreneurs, Entrepreneurship conference, Faculty of Management, National University of Political Studies and Public Administration, Bucharest, Romania, 18-20 May 2017.

\section{References}

Acs, Z.J., Szerb, L., \& Autio, E. (2017). Global Entrepreneurship Index 2016. Washington, DC: The Global Entrepreneurship and Development Institute. Ahmad, S.Z. (2015). Entrepreneurship education in tourism and hospitality programs. Journal of Hospitality \& Tourism Education, 27(1), 20-29.

Athayde, R. (2009). Measuring enterprise potential in young people. Entrepreneurship Theory and Practice, 33(2), 481-500.

Bayaga, A. (2010). Multinomial logistic regression: Usage and application in risk analysis. Journal of Applied Quantitative Methods, 5(2), 288-297.

Bonwell, C., \& Eison, J. (1991). Active Learning: Creating Excitement in the Classroom. Washington, DC: The George Washington University.

Chang, J., \& Rieple, A. (2013). Assessing students' entrepreneurial skills development in live projects. Journal of Small Business and Enterprise Development, 20(1), 225-241.

Chell, E. (2008). The Entrepreneurial Personality: A Social Construction. London: Routledge.

Chell, E. (2013). Review of skill and the entrepreneurial process. International Journal of Entrepreneurship Behaviour and Research, 19(1), 6-31. 
Chiru, C., Tachiciu, L., \& Ciuchete, S.G. (2012). Psychological factors: Behavioural variables and acquired competencies in entrepreneurship education. Procedia-Social and Behavioural Sciences, 46, 4010-4015.

Cope, J. (2003). Entrepreneurial learning and critical reflection: Discontinuous events as triggers for 'higher-level' learning. Management Learning, 34, 429-450.

Corbett, A.C. (2005). Experimental learning within the process of opportunity identification and exploitation. Entrepreneurship Theory and Practice, 29, 473-491.

Covin, J.G., \& Wales, W.J. (2012). The measurement of entrepreneurial orientation. Entrepreneurship Theory and Practice, 36(4), 677-702.

Cui, Y., Sun, C., Xiao, H., \& Zhao, C. (2016). How to become an excellent entrepreneur: The moderating effect of risk propensity on alertness to business ideas and entrepreneurial capabilities. Technological Forecasting \& Social Change, 112, 171-177.

Cunningham, J. (1991). Defining entrepreneurship. Journal of Small Business Management, 29(1), 45-61.

Daniel, A.D., Costa, R.A., Pita, M., \& Costa, C. (2017). Tourism Education: What about entrepreneurial skills? Journal of Hospitality and Tourism Management, 30, 65-72.

Deakins, D., \& Freel, M. (1998). Entrepreneurial learning and the growth process in SMEs. The Learning Organization, 5, 144-155.

Draycott, M.C., \& Rae, D. (2011). Enterprise education in schools and the role of competency frameworks. International Journal of Entrepreneurial Behaviour \& Research, 17(2), 127-145.

Draycott, M.C., Rae, D., \& Vause, K. (2011). The assessment of enterprise education in the secondary education sector: A new approach? Education + Training, 53(8/9), 673-691.

European Commission (2008, March 30). Best Procedure Project: Entrepreneurship in Higher Education, Especially in Non-Business Studies. Final Report of the Expert Group. Retrieved from http://ec.europa.eu/ enterprise/entrepreneurship/supportmeasures/training education/index. $\mathrm{htm}$

European Commission (2012, September 20). Rethinking Education: Investing in skills for better socio-economic outcomes. Retrieved from http:// ec.europa.eu/education/policy/multilingualism/rethinking-education/en

European Commission (2013, January 9). Entrepreneurship 2020 action plan: Reigniting the entrepreneurial spirit in Europe. Retrieved from http://eurlex.europa.eu/LexUriServ/LexUriServ.do?uri=COM:2012:0795:FIN:en:PDF

European Council (2006, December 30). Recommendation of the European parliament and the council of 18 December 2006 on key competences for lifelong learning. Retrieved from http://eur-lex.europa.eu/legal-content/ EN/TXT/PDF/?uri=CELEX:32006H0962\& from=EN

Fayolle, A. (2013). Personal views on the future of entrepreneurship education. Entrepreneurship \& Regional Development, 25(7-8), 692-701. 
Frese, M. (2007). Performance - an action theory approach. In J.R. Baum, M. Frese \& R. Baron (Eds.), The Psychology of Entrepreneurship (pp. 151-188). London: Lawrence Erlbaum.

GEM (2014). Informe GEM España 2014. Santander: Universidad de Cantabria. Gibb, A.A. (2002). Creating conducive environments for learning and entrepreneurship: Living with, dealing with, creating and enjoying uncertainty and complexity. Industry \& Higher Education, 16(3), 135-148. Gundry, L.K., Ofstein, L.F., \& Kickul, J.R. (2014). Seeing around corners: How creativity skills in entrepreneurship education influence innovation in business. International Journal of Management Education, 12(3), 529-538. Hall, E.T. (1981). The Silent Language. New York: Doubleday.

Hamilton, E. (2011). Entrepreneurial learning in family business: a situated learning perspective. Journal of Small Business and Enterprise Development, 18(1), 8-26.

Hannon, P. D. (2006). Teaching pigeons to dance: Sens and meaning in entrepreneurship education. Education + Training , 48(5), 296-308.

Hodzic, S. (2016). Increasing PhD students' employability by focusing on the academic entrepreneurship. The analysis of the entrepreneurial competences. Tuning Journal for Higher Education, 3(2), 347-387.

Hoffman, J. (2004). Generalized Linear Models. Boston: Pearson Education Inc. Hofstede, G. (2001). Culture's Consequences: Comparing Values, Behaviors, Institutions, and Organizations Across Nations. Thousand Oaks, CA: Sage Publications.

House, R.J., Hanges, P.J., Javidan, M, Dorfman, P.W., \& Gupta, V. (2004). Culture, Leadership and Organizations: The GLOBE Study of 62 Societies. Thousand Oaks, CA: Sage Publications.

Itim International (2017, March 25). Geert Hofstede. National culture. Retrieved on from https://geert-hofstede.com/national-culture.html

Karatas-Ozkan, M. (2011). Understanding relational qualities of entrepreneurial learning: towards a multi-layered approach. Entrepreneurship and Regional Development, 23, 877-906.

Katz, J.A. (2008). Fully mature but not fully legitimate: A different perspective on the state of entrepreneurship education. Journal of Small Business Management \& Marketing, 46(4), 550-566.

Kluckhohn, F., \& Strodbeck, F. (1961). Variations in Value Orientations. Evanston, IL: Row, Peterson.

Landström, H., Harirchi, G., \& Åström, F. (2012). Entrepreneurship: Exploring the knowledge base. Research Policy, 41(7), 1154-1181.

Lans, T., Verstegen, J., \& Mulder, M. (2011). Analysing, pursuing and networking: Towards a validated three-factor framework for entrepreneurial competence from a small firm perspective. International Small Business Journal, 29(6), 695-713.

Le Deist, F. D., \& Winterton, J. (2005). What is competence? Human Resource Development International, 8(1), 27-46. 
Leon, R. D. (2014). University's contribution to the development of the future knowledge workers. In F. Uslu (Ed.), Proceedings of INTCESS14International Conference on Education and Social Sciences (pp. 313-322). Istanbul: OCERINT.

Leon, R.D. (2015). The future knowledge worker: An intercultural perspective. Management Dynamics in the Knowledge Economy, 3(4), 675-691.

Leon, R.D. (2016). The development of the future european knowledge workers. An academic perspective. Management Dynamics in the Knowledge Economy, 4(3), 339-356.

Man, T.W.Y. (2012). Developing a behaviour-centred model of entrepreneurial learning. Journal of Small Business and Enterprise Development, 19(3), 549-566.

Mitchelmore, S., \& Rowley, J. (2010). Entrepreneurial competencies: A literature review and development agenda. International Journal of Entrepreneurial Behavior \& Research, 16(2), 92-111.

Moberg, K. (2014). Two approaches to entrepreneurship education: The different effects of education for and through entrepreneurship at the lower secondary level. The International Journal of Management Education, 12(3), 512-528.

Moberg, K., Vestergaard, L., Fayolle, A., Redford, D., Cooney, T., Singer, S., . . Filip, D. (2014). How to Assess and Evaluate the Influence of Entrepreneurship Education: A Report of the ASTEE Project with a User Guide to the Tools. Copenhagen: The Danish Foundation for Entrepreneurship - Young Enterprise.

Moksony, F., \& Hegedus, R. (2014). The use of Poisson regression in the sociological study of suicide. Corvinus Journal of Sociology and Social Policy, 5(2), 97-114.

Morris, M.H., Webb, J.W., Fu, J., \& Singhal, S. (2013). A competency-based perspective on entrepreneurship education: Conceptual and empirical insights. Journal of Small Business Management, 51(3), 352-369.

Pittaway, L., \& Edwards, C. (2012). Assessment: Examining practice in entrepreneurship education. Education + Training, 54(8/9), 778-800.

Rae, D., \& Carswell, M. (2000). Using a life-story approach in researching entrepreneurial learning: the development of a conceptual model and its design of learning experiences. Education + Training, 42(4/5), 220-227.

Schelfhout, W., Bruggeman, K., \& de Maeyer, S. (2016). Evaluation of entrepreneurial competence through scaled behavioural indicators: Validation of an instrument. Studies in Educational Evaluation, 51, 29-41.

Schelfhout, W., Dochy, F., \& Janssens, S. (2004). The use of self, peer and teacher assessment as a feedback system in a learning environment aimed at fostering skills of cooperation in an entrepreneurial context. Assessment \& Evaluation in Higher Education, 29(2), 177-201.

Schenkel, M.T., Matthews, C.H., \& Ford, M. W. (2009). Making rational use of 'irrationality'? Exploring the role of need for cognitive closure in nascent 
entrepreneurial activity. Entrepreneurship \& Regional Development, 21(1), 51-76.

Seuneke, P., Lans, T., \& Wiskerke, J.S.C. (2013). Moving beyond entrepreneurial skills: Key factors driving entrepreneurial learning in multifunctional agriculture. Journal of Rural Studies, 32, 208-219.

Taatila, V., \& Down, S. (2012). Measuring entrepreneurial orientation of university students. Education Training, 54(8/9), 744-760.

Tabachnick, B.G., Fidell, L.S., \& Osterlind, S.J. (2001). Using Multivariate Statistics. Boston: Allyn and Bacon.

Tiwari, A. (2011). Nurturing entrepreneurship competencies through education: Reflection from entrepreneurs \& teacher's. Asia Pacific Journal of Research in Business Management, 2(10), 136-145.

Triandis, H.C. (1995). Individualism and Collectivism. Boulder: Westview.

Trompenaars, F. (1993). Riding the Waves of Culture: Understanding Cultural Diversity in Business. London: Economics Books.

Zahra, S.A., Sapienza, H.J., \& Davidsson, P. (2006). Entrepreneurship and dynamic capabilities: a review, model and research agenda. Journal of Management Studies, 43(4), 917-955.

\section{Abstract (in Polish)}

Celem badań jest ustalenie, $w$ jaki sposób uczelnie ekonomiczne $i$ biznesowe państw członkowskich Unii Europejskiej przyczyniajq się do rozwoju umiejętności przedsiębiorczych studentów. Dlatego stosuje się strategię studiów przypadku, która koncentruje się na najważniejszych szkołach biznesu z państw członkowskich Unii Europejskiej; w ten sposób zidentyfikowano i przeanalizowano 267 syllabusów z 21 uczelni wyższych. Wyniki pokazujq, że europejskie szkoły biznesu zdołały rozwinq̨́ większość wymaganych umiejętności w zakresie przedsiębiorczości wśród swoich studentów. Ich absolwenci sq zorientowani zarówno na zadania, jak i na ludzi. Z jednej strony ceniq sobie wydajność, sq $w$ stanie rozwiqzywać problemy i podejmować skalkulowane ryzyko. Z drugiej strony wiedzq, jak komunikować się i współpracować w ramach zespołu. Ponadto można stwierdzić, że analizowane programy edukacyjne łaczq podejście "o przedsiębiorczości” z perspektywq „dla przedsiębiorczości”; koncentrujq się na rozwijaniu kompetencji poznawczych, funkcjonalnych i behawioralnych poprzez łq̨czenie wykładów z aktywnymi technikami uczenia się. Działania te zależq od specyfiki kulturowej i majq wpływ na zdolność danego kraju do osiqgnięcia najwyższej skuteczności w zakresie rozwoju przedsiębiorczości. Odkrycia te maja zarówno teoretyczne, jak i praktyczne implikacje. Na poziomie teoretycznym poszerzajq literature dotyczqca rozwoju umiejętności przedsiębiorczych, dostarczajqc konkretnych informacji o umiejętnościach, na których koncentrujq się programy akademickie. Na poziomie praktycznym zapewniajq one cenny wglqad w umiejętności, które będq mieli przyszli przedsiębiorcy; wpłynie to na ich zachowanie w środowisku biznesowym, niezależnie od tego, czy zdecydujq się oni być właścicielami firmy, czy przedsiębiorczym pracownikiem. Słowa kluczowe: przedsiębiorczość, podejmowanie ryzyka, komunikacja, Uniwersytet, Unia Europejska. 


\section{Biographical note}

Ramona - Diana Leon is a Lecturer in Management Simulations and Knowledge Management at the National University of Political and Public Administration. She received her PhD in Management from the "Alexandru loan Cuza" University of lasi. She has worked in several projects about knowledge management, strategic management, and quality management in various sectors of activity such as education, textile and consulting services. Her main teaching and research interests lie in the areas of knowledge management and strategic management, with a special focus on intellectual capital valuation and strategic implications. In the last five years, Ramona has published several books, book chapters and articles in the field of knowledge management, strategic management, quality management, intellectual capital and emotional intelligence. In addition, she serves on the editorial boards of numerous international and national journals and conferences and is a full member of the International Association for Knowledge Management. She also has wide experience in Europe, collaborating with academics and managers from Romania and Spain. 
